\title{
The Environmental Mandate of the ISA
}

\subsection{Introduction}

Of all issue areas in the law of the sea, none enjoyed greater international agreement than the need to preserve and protect ocean space from manmade degradation. ${ }^{1}$

The previous chapter set out the International Seabed Authority's (ISA) general mandate, institutional structure, and decision-making processes. Against this background, this chapter explores the environmental mandate of the ISA under the United Nations Convention on the Law of the Sea (LOSC or Convention $)^{2}$ and the Agreement Relating to the Implementation of Part XI of the United Nations Convention on the Law of the Sea (IA). ${ }^{3}$ This provides an overview of the overarching obligations of the ISA in relation to the protection of the marine environment and their historical context. Building on this analysis, Chapter 5 then examines how the ISA has developed its specific environmental obligations further, through its law-making powers and the adoption of the Mining Code.

From the outset of the negotiations of the LOSC it was recognised as inevitable that deep seabed mining would have environmental consequences. In order to effectively implement the objectives of the LOSC, including those on the protection and preservation of the marine environment set out in Part XII, ${ }^{4}$ it was accepted that the ISA would require a comprehensive environmental mandate. Consequently, the ISA is required not only to administer and regulate seabed mining activities in the Area on behalf of humankind, but it is also obligated, under the LOSC, to ensure effective protection for the marine environment from the potentially harmful effects of such mining activities.

1 Christopher C. Joyner, 'The Antarctic Treaty System and the Law of the Sea-Competing Regimes in the Southern Ocean' (1995) 10(2) The International Journal of Marine and Coastal Law 301-331, page 311.

2 United Nations Convention on the Law of the Sea (adopted 10 December 1982, entered into force 16 November 1994) 1833 UNTS 3.

3 Agreement Relating to the Implementation of Part XI of the United Nations Convention on the Law of the Sea (adopted 28 July 1994, entered into force 28 July 1996) 1836 UNTS 3 .

4 See also LOSC, preamble paragraph 4. 
Both aims are two sides of the same coin, and it is left for the ISA to strike the appropriate balance between these competing demands.

This dynamic between management of seabed mining and marine environmental protection is what makes the ISA both an interesting and an important case-study. It also raises the question of whether the ISA's competencies might enable it to play an important role in the wider quest for sustainable ocean governance in areas beyond national jurisdiction. ${ }^{5}$ With this in mind, the present chapter provides an analysis of the ISA's environmental competencies and responsibilities. In doing so, the chapter situates the ISA's competencies in the context of general developments with regard to improving regulation and governance of marine biodiversity in areas beyond national jurisdiction.

The chapter begins with a discussion in Section 4.2 of the historical context in which the ISA's environmental mandate was established. Subsequently, Section 4.3 provides an analysis of the specific LOSC and IA provisions that form the ISA's environmental mandate as well as the core environmental obligations of the ISA member states. Section 4.4 explores the extent to which the obligation to apply the precautionary principle has been gradually integrated into the LOSC. Lastly, Section 4.5 discusses the ISA's mandate over marine scientific research in the context of the debate around bioprospecting.

\subsection{Environmental Considerations During the Negotiations of Part XI and the Implementing Agreement}

The problem of marine pollution was appreciated as early as the 1920s, when the first efforts were made to regulate vessel-source pollution. ${ }^{6}$ By the 1960 s awareness of the serious and growing impact of marine pollution had become widespread. ${ }^{7}$ When deep ocean mineral mining became a serious topic of conversation in the 1960 s, it was clear that this new activity would contribute to existing challenges with respect to the protection of the marine environment.

5 Chapters 4.5, 5.4.2.1.

6 Alan Khee-Jin Tan, Vessel-Source Marine Pollution: The Law and Politics of International Regulation (Cambridge University Press, 2005), pages 107-109; Patricia Birnie, Alan Boyle and Catherine Redgwell, International Law and the Environment (3rd ed, Oxford University Press, 2009), page 379 .

7 Evan Luard, The Control of the Sea-Bed: A New International Issue (Heinemann, 1974), page 76; Birnie, Boyle, and Redgwell (n. 6), page 380; Gwénaëlle Le Gurun, 'Environmental Impact Assessment and the International Seabed Authority' in Timo Koivurova and C.J. Bastmeijer (eds) Theory and Practice of Transboundary Environmental Impact Assessment (Brill, 2007) 221-264, pages 225-226. 
These early concerns were given voice in the 1970 Declaration of Principles Governing the Seabed and the Ocean Floor, and the Subsoil Thereof, beyond the Limits of National Jurisdiction in which states agreed that:

With respect to activities in the area and acting in conformity with the international régime to be established, States shall take appropriate measures for and shall co-operate in the adoption and implementation of international rules, standards and procedures for, inter alia:

(a) The prevention of pollution and contamination, and other hazards to the marine environment, including the coastline, and of interference with the ecological balance of the marine environment;

(b) The protection and conservation of the natural resources of the area and the prevention of damage to the flora and fauna of the marine environment. ${ }^{8}$

This provision captures wide-ranging environmental protection concerns that appear to support protective measures 'in the most comprehensive and allembracing manner. ${ }^{9}$ Interestingly, when referring to activities in the Area, the Declaration is not limited to mineral activities but encompassed any activity that can conceivably take place in the Area. ${ }^{10}$ Paragraphs 12 and 14 of the Declaration highlight this wide scope by noting that 'activities in the area, including those relating to its resources,' must conform to specific standards.

This provision built the basis for subsequent negotiations of the provisions of the LOSC that set out the ISA's environmental mandate. However, during the UNCLOS III negotiations, the Declaration's broad scope was narrowed to define 'activities in the Area' restrictively, by reference only to mineral exploration and exploitation activities. ${ }^{11}$ Thus, the Losc departed from the comprehensive focus of protecting the Area from all potentially harmful interferences and instead confirmed a single-sector mandate for the IsA. ${ }^{12}$ This can be explained by the concern of industrialised states, outlined in

8 UNGA, Un Doc A/RES/2749(XXv) (17 December 1970), paragraph 11 (emphasis added).

9 Myron H. Nordquist et al., United Nations Convention on the Law of the Sea, 1982: A Commentary, Volume IV (Martinus Nijhoff Publishers, 1991), page 10.

10 Peter B. Payoyo, Cries of the Sea: World Inequality, Sustainable Development and the Common Heritage of Humanity (Martinus Nijhoff Publishers, 1997), pages 334-337.

11 Losc, article 1(1)(3); Satya N. Nandan, Michael W. Lodge, and Shabtai Rosenne, United Nations Convention on the Law of the Sea, 1982: A Commentary, Volume VI (Martinus Nijhoff Publishers, 2002), pages 192-194. 
Chapter 3.2, which wanted to see 'the Authority possess as little discretionary powers as possible. ${ }^{13}$ Nevertheless, the Preamble to the Losc expressly references the Declaration and calls for the further development of the principles enshrined therein. ${ }^{14}$

Overall, environmental concerns continued to play an important role during the negotiations of the LOSC, not least because UNCLOS III commenced in 1972, the same year the United Nations Conference on the Human Environment was held in Stockholm. The conference not only 'stimulated the widespread attention to the global environment that has continued to the present' ${ }^{15}$ but also influenced negotiations at UNCLOS III. ${ }^{16}$ Indeed, as discussed in Section 4.3.3, Principle 7 of the Stockholm Declaration on the Human Environment, calling on states to prevent marine pollution, ${ }^{17}$ found detailed application in the LOSC.

As will be recalled from Chapter 3.2, Part XI of the LOSC remained controversial even after the adoption of the Losc. The informal consultations from 1990 to 1994, aimed at its amendment, addressed the concerns of industrialised states with respect to the future seabed mining regime for the Area. At the outset of the informal consultations, environmental considerations were identified as a point of concern. ${ }^{18}$ However, by 1992 it had become apparent that there were no areas of disagreement that would require modification of the environmental obligations the LOSC places on both states parties and the ISA. ${ }^{19}$ Indeed, the Preparatory Commission for the ISA had simultaneously been developing a set of draft environmental rules for the seabed mining regime

\footnotetext{
13 Ibid.

14 Losc, preamble, para. 6.

15 Jonathan I. Charney, 'The Marine Environment and the 1982 United Nations Convention on the Law of the Sea' (1994) 28 The International Lawyer 879-901, page 883.

16 David Anderson, Modern Law of the Sea (Martinus Nijhoff Publishers, 2008), page 13.

17 Report of the United Nations Conference on the Human Environment, Stockholm, 5-16 June 1972, A/Conf.48/14/Corr. 1, 11 ILM 1416 (1972).

18 'Information Note Concerning the Secretary-General's Informal Consultation on Outstanding Issues Relating to the Deep Seabed Mining Provisions of the UN Convention on the Law of the Sea, New York, 25 March 1991', reprinted in ISA, Secretary-General's Informal Consultations on Outstanding Issues Relating to the Deep Seabed Mining Provisions of the United Nations Convention on the Law of the Sea: Collected Documents (ISA, 2002), 13-20, page 13 .

19 'Summary of Informal Consultations Conducted by the Secretary-General on the Law of the Sea During 1990 and 1991 (31 January 1992)', reprinted in ISA (n. 18) 65-78, paragraph 45; Nandan, Lodge, and Rosenne (n. 11), page 197.
} 
without encountering any 'insurmountable obstacles' in the progress. ${ }^{20}$ As a result, it was agreed that 'this was not a controversial issue' and that environmental concerns were therefore 'qualitatively different' from the disputed aspects surrounding Part XI. ${ }^{21}$ Therefore, environmental considerations were removed from the list of obstacles, ${ }^{22}$ without in any way reducing their importance. ${ }^{23}$ In Anderson's words, 'there was general agreement that environmental considerations were of utmost importance and that the Convention already imposed high standards which would be further elaborated by the Authority. This question was not seen to be one which represented an obstacle in the way of ensuring universal participation. ${ }^{24}$

The 12 years between the conclusions of the LOSC in 1982 and the adoption of the IA in 1994, were characterised by a growing awareness of the urgency of environmental protection. ${ }^{25}$ Several significant multilateral environmental agreements were adopted, including the Convention on Biological Diversity, ${ }^{26}$ and the Convention for the Protection of the Marine Environment of the NorthEast Atlantic. ${ }^{27}$ Moreover, advances in research into the deep sea environment uncovered new knowledge about the scientific and economic potential of deep ocean ecosystems and living organisms. ${ }^{28}$ It is hardly surprising then that the IA addressed such growing environmental consciousness. Its preamble specifically highlights 'the importance of the Convention for the protection and preservation of the marine environment and of the growing concern for the global environment.' 29 What is more, states agreed that the protection of the deep sea environment must not only be part of the ISA's mandate but in fact a priority area on which the ISA should concentrate before approving the first

20 Summary of Informal Consultations Conducted by the Secretary-General (n. 19), paragraph 46.

21 Ibid.

22 UNGA, UN Doc A/48/950 (9June 1994), paragraph 9.

23 See for example Nandan, Lodge, and Rosenne (n. 11), pages 197-199.

24 Anderson (n. 16), page 310.

25 Bernard H. Oxman, 'The 1994 Agreement and the Convention' (1994) 88(4) The American Journal of International Law 687-696, page 688.

26 Convention on Biological Diversity (adopted 5 June 1992, entered into force 29 December 1993) 1760 UNTS 79 .

27 Convention for the Protection of the Marine Environment of the North-East Atlantic (adopted 22 September 1992, entered into force 25 March 1998) 2354 UNTs 67.

28 See for example Maria C. Baker et al., 'Biogeography, Ecology, and Vulnerability of Chemosynthetic Ecosystems in the Deep Sea' in Alasdair McIntyre (ed), Life in the World's Oceans: Diversity, Distribution, and Abundance (Wiley-Blackwell, 2010) 161-182.

29 IA, preamble paragraph 3. 
exploitation contract. ${ }^{30}$ This was intended to include the adoption of binding rules, regulations and procedures setting applicable environmental protection standards ${ }^{31}$ as well as the 'timely elaboration of rules, regulations and procedures for exploitation, including those relating to the protection and preservation of the marine environment. ${ }^{32}$

In sum, the need to address the environmental risks of seabed mining was recognised from the very start of developing the regime. Thus, the LOSC incorporates extensive environmental obligations, which are discussed in this chapter. Furthermore, despite the powers and functions of the ISA having been at the core of the controversy around Part XI in the early 1990s, the ISA's mandate to ensure effective protection of the marine environment was not challenged. On the contrary, the IA strengthened the importance of the Authority's environmental obligations by identifying them as a priority task.

\subsection{The General Obligation Under the Convention and the Implementing Agreement to Protect and Preserve the Marine Environment}

\subsubsection{The Obligation to Protect and Preserve the Marine Environment}

The adoption of the LOSC presented a major step for international law relating to the marine environment. ${ }^{33}$ Part XII of the LOSC is dedicated to the broad objective captured in Article 192 of protecting and preserving the marine environment. As an umbrella convention, Part XII of the LOSC addresses the growing problem of marine pollution and environmental degradation in a comprehensive, global manner rather than a regional or sector-based approach. ${ }^{34}$ Part XI of the LOSC complements this global focus with a sectorspecific allocation of competencies to the ISA.

The scope of Part XII encompasses not only marine pollution but affects any human activity that impacts on marine environmental protection and

\footnotetext{
30 IA, annex section $1(5)$.

31 IA, annex section $1(5)(\mathrm{g})$.

32 IA, annex section $1(5)(\mathrm{k})$.

33 Charney (n. 15).

34 David M. Ong, 'The 1982 UN Convention on the Law of the Sea and Marine Environmental Protection' in Malgosia Fitzmaurice, David M. Ong, and Panos Merkouris, Research Handbook on International Environmental Law (Edward Elgar Publishing, 2010) 567-585, pages 568-569; Moira L. McConnell and Edgar Gold, 'Modern Law of the Sea: Framework for the Protection and Preservation of the Marine Environment?' (1991) 23 Case Western Reserve Journal of International Law 83-105, page 85.
} 
preservation. ${ }^{35}$ While not setting specific protection standards, Part XII comprises general environmental protection principles ${ }^{36}$ and lays down the broad legal framework within which all law-making on the marine environment must now take place. ${ }^{37}$ These general rules, rights, and obligations are then refined by the rules applying to an individual regime or activity.

The broad and all-encompassing aim to protect and preserve the marine environment also underpins the IsA's mandate which is discussed in the following sections in two parts. The first part examines the obligation incumbent on the ISA to protect the marine environment from damage caused by seabed mining, while the second part concentrates on the corresponding obligations of states. Both are separate obligations although they naturally overlap, as the ISA consists of member states and the European Union. Any failure on the part of the ISA to meet its environmental obligations will therefore also affect the assessment of whether or not the member states have met their corresponding environmental obligations and vice versa.

Moreover, while the rules on the ISA regime are set out primarily in Part XI of the LOSC, other parts of the Convention are also relevant. In addition, as confirmed by Article 31(3)(c) of the Vienna Convention on the Law of Treaties, ${ }^{38}$ in interpreting a treaty both the context and 'any relevant rules of international law applicable in the relations between the parties' can be taken into account. These include rules contained in the LOsC outside of Part XI. ${ }^{39}$ After all, as an international organisation the ISA operates within the broader context of international law and is bound by general rules of international law ${ }^{40}$ and customary international law. ${ }^{41}$ This affects the environmental mandate of the ISA, which, as the present chapter will demonstrate, reflects international environmental legal principles, such as the obligation to apply the precautionary approach.

\footnotetext{
35 McConnell and Gold (n. 34), page 86.

$36 \quad$ Nordquist et al. (n. 9), page 21.

37 Ong (n. 34), page 570.

38 Vienna Convention on the Law of Treaties (adopted 23 May 1969, entered into force 27 January 1980) 1155 UNTS 331 (VCLT).

39 wто, Canada-Measures Affecting the Export of Civilian Aircrafts, WT/DS7o/AB/R (2 August 1999), paragraphs 155-156; Richard Gardiner, Treaty Interpretation (Oxford University Press, 2008), pages 177-178, 182-186, 260.

$40 \quad$ Interpretation of the Agreement of 25 March 1951 Between the WHO and Egypt (Advisory Opinion of 20 December 1980) [1980] ICJ Rep 73, pages 89-9o; Henry G. Schermers and Niels M. Blokker, International Institutional Law (vol. 5, Martinus Nijhoff Publishers, 2011), pages $833^{-835}, 995^{-998 .}$

Schermers and Blokker (n. 40), page 835 .
} 


\subsubsection{The Environmental Mandate of the ISA}

When delivering his speech in 1967,42 Ambassador Pardo envisaged the future international agency 'as the body with over-all responsibility for keeping the problem of ocean pollution under control.43 Although the LOSC limited the ISA's mandate to seabed mining, it nonetheless imposed a comprehensive obligation on the IsA to ensure seabed mining in the Area would not undermine the overall aim of protecting the marine environment. Under Article 145, the ISA is required to take:

necessary measures [...] in accordance with this Convention with respect to activities in the Area to ensure effective protection for the marine environment from harmful effects which may arise from [activities in the Area].

This provision assigns the primary responsibility for preventing environmental harm resulting from mining activities in the Area to the ISA. ${ }^{44}$ At the same time it grants the ISA a broad capacity to enact protective measures as it deems necessary. Article 145 continues specifically to require the ISA to adopt appropriate rules, regulations and procedures, including for:

the prevention, reduction and control of pollution and other hazards to the marine environment, including the coastline, and of interference with the ecological balance of the marine environment, particular attention being paid to the need for protection from harmful effects of such activities as drilling, dredging, excavation, disposal of waste, construction and operation or maintenance of installations, pipelines and other devices related to such activities; [and]

the protection and conservation of the natural resources of the Area and the prevention of damage to the flora and fauna of the marine environment. 45

Article 145 sets the framework for environmental protection from seabed mining in the Area and it provides some guidance as to the subjective environmental conservation objectives the ISA must adopt. Nevertheless, the list of activities

\footnotetext{
42 Chapter 3.2.

43 UNGA, Un Doc A/C.1./PV.1516 (1 November 1967), paragraph 10.

44 Nandan, Lodge, and Rosenne (n. 11), page 194.

45 LOSC, article 145 (emphasis added); see also Losc, annex III article 17(1)(b)(xii); IA, annex section $1(5)(\mathrm{g})$.
} 
named in Article 145 that require protective measures is non-exhaustive. Indeed, Article 17(2)(f) of Annex III to the Losc lists further activities:

Rules, regulations and procedures shall be drawn up in order to secure effective protection of the marine environment from harmful effects directly resulting from activities in the Area or from shipboard processing immediately above a mine site of minerals derived from that mine site, taking into account the extent to which such harmful effects may directly result from drilling, dredging, coring and excavation and from disposal, dumping and discharge into the marine environment of sediment, wastes or other effluents.

In the context of this broad obligation to protect the environment, it should be recalled that while the Council has the competence to adopt new regulations, ${ }^{46}$ the Legal and Technical Commission is required to formulate and submit to the Council environmental rules, regulations, and procedures and keep them under review. ${ }^{47}$ Moreover, the Legal and Technical Commission has to make recommendations to the Council on 'the protection of the marine environment, taking into account the views of recognized experts in that field.'48 Here, it should be noted that the ISA also has the competence to issue emergency orders to prevent serious environmental harm in critical situations. Such orders may include suspension or adjustment of operations. ${ }^{49}$ Furthermore, the general and specific competencies of the ISA are supplemented by incidental powers under Article 157 of the LOSC and Section 1(1) of the annex to the 1994 Agreement.

These provisions grant the IsA a general and far-reaching environmental mandate, which was given additional emphasis under the IA. Section $1(5)(\mathrm{g})$ of the Annex to the IA requires the ISA to give priority to the adoption of rules, regulations, and procedures that incorporate applicable standards for the protection and preservation of the marine environment. Several points may be observed in relation to the IsA's general environmental mandate.

First, Article 145 elaborates upon the principle in Article 209, ${ }^{50}$ which generically enunciates that international rules, regulations and procedures shall be established in accordance with Part XI to prevent, reduce and control

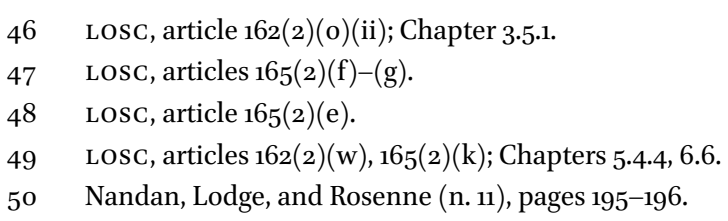


pollution of the marine environment from activities in the Area. ${ }^{51}$ The obligation to establish such international rules is clearly assigned to the ISA under Article 145. However, Article 209(2) also requires states to adopt corresponding laws and regulations to prevent pollution from any activities in the Area involving vessels flying their flag or other structures or installations operating under their authority. Importantly though, 'such laws and regulations shall be no less effective than the international rules, regulations and procedures' 52 adopted by the ISA. As such, Article 209 grants a preferential role to the regime created by the ISA in accordance with Part XI as regards the protection of the environment from pollution in the Area. ${ }^{53}$

Similarly, states who engage in seabed mining in areas within their national jurisdiction are required to adopt pollution prevention laws, regulations, and measures under Article 208, which must be no less stringent than international rules. Consequently, the effects of the IsA's environmental mandate extend beyond the Area regime and directly set a benchmark for pollution standards adopted under domestic legislation.

Second, in setting environmental standards, the ISA must be guided by Part XII of the LOSC. In fact, a previous draft of Article 145 referred specifically to the need to take protective measures 'in accordance with Part XII' of the LosC. ${ }^{54}$ The wording was ultimately replaced by the requirement to act 'in accordance with this Convention. 55

Of particular relevance is Article 197 in Part XII which sets out the need to take into account 'characteristic regional features' of marine environments. In the deep ocean context, this requires particular attention to be given to unique and largely unchartered ecosystems and organisms.

Lastly, and indeed importantly, Article 145 provides for the protection of the marine environment as a whole, including flora and fauna. Although the ISA's mandate is limited to seabed mining activities, as discussed in Section 4.2 above, it is not spatially restricted. Indeed, the requirement to prevent 'interference with the ecological balance of the marine environment' recognises the integrated nature of marine ecosystems and includes in that obligation not

$5^{1}$ Article 209 is complemented by article 215 which provides that enforcement of these international rules is to be governed by Part XI.

$5^{2} \quad$ LOSC, article 209(2), annex III article 21(3).

53 Tullio Scovazzi, 'Mining, Protection of the Environment, Scientific Research and Bioprospecting: Some Considerations on the Role of the International Sea-Bed Authority' (2004) 19(4) The International Journal of Marine and Coastal Law 383-410, page 394.

54 Nandan, Lodge, and Rosenne (n. 11), page 195.

55 Losc, article 145. 
only the seabed but also the water column, coastal areas, as well as 'other parts of the environmental continuum of the oceans. 56

Moreover, the ISA's environmental mandate comprises the protection of marine flora and fauna regardless of whether or not they form part of the Area. This becomes especially relevant in light of the ongoing debate over marine genetic resources. ${ }^{57}$ The realisation that living organisms in the deep ocean hold commercially promising genetic information has sparked a debate over who should have access to these so-called 'marine genetic resources' and how the benefits might be shared. ${ }^{58}$ Part of the debate focuses on whether or not those marine genetic resources that are sedentary species, living on the ocean floor, should be regarded as forming part of the Area and thus the common heritage of humankind. ${ }^{59}$

In brief, some states and scholars argue that if the economic potential of marine genetic resources had been known at the time of UNCLOS III, marine genetic resources would have been included in the definition of 'resources' in Part XI. ${ }^{60}$ Moreover, the Part VI continental shelf regime applies to non-living, natural resources of the seabed and subsoil as well as to living organisms belonging to sedentary species, ${ }^{61}$ which are defined as those species 'which, at the harvestable stage, either are immobile on or under the seabed or are unable to move except in constant physical contact with the seabed or the subsoil.'62 If the same distinction was to be applied to sedentary species beyond the continental shelf these resources would form part of the Area, and thus part of

$56 \quad$ Nandan, Lodge, and Rosenne (n. 11), page 196.

57 See also Section 4.5 .

$5^{8}$ For a detailed discussion of the debate, see Robin Warner, Protecting the Oceans Beyond National Jurisdiction: Strengthening the International Law Framework (Martinus Nijhoff Publishers, 2009), chapter 7; Nele Matz, 'Marine Biological Resources: Some Reflections on Concepts for the Protection and Sustainable Use of Biological Resources in the Deep Sea' (2002) 2 Non-State Actors and International Law 279-300.

59 BвNJ Working Group, UN Doc A/67/95 (13 June 2012), paragraph 15-19.

6o See for example Frida Armas-Pfirter, 'How can Life in the Deep Sea be Protected?' (2009) 24(2) The International Journal of Marine and Coastal Law 281-307; Louise Angélique de La Fayette, 'Institutional Arrangements for the Legal Regime Governing Areas Beyond National Jurisdiction—Commentary on Tullio Scovazzi' in Alex G. Oude Elferink and Erik Jaap Molenaar (eds) The International Legal Regime of Areas beyond National Jurisdiction: Current and Future Developments (Martinus Nijhoff Publishers, 2010) 77-79; Fernanda Millicay, 'A Legal Regime for the Biodiversity of the Area' in Myron H. Nordquist et al. (eds) Law, Science and Ocean Management (Martinus Nijhoff Publishers, 2007) 739-850; BBNJ Working Group, UN Doc A/61/65 (20 March 2006), paragraph 71.

$61 \quad$ LOSC, articles $77(4), 68$.

$62 \quad$ LOsC, article $77(4)$. 
the common heritage of mankind ${ }^{63}$ possibly leading to their inclusion within the mandate of the ISA. Opposing views have been expressed by delegations, who interpret the seabed regime narrowly as only covering mineral resources in accordance with Article 133(a) of the LOSC. These delegations argue that all other resources are subject to the high seas regime. ${ }^{64}$

In light of this debate, it must be noted that Article 145 already provides for the protection of all flora and fauna at least from adverse effects of seabed mining. Corresponding to Article 192, this obligation is not restricted to flora and fauna that were known at the time of negotiating the Convention. As a result, the existing environmental mandate of the Authority is independent of the ongoing debate over the status of marine genetic resources. ${ }^{65}$

It becomes clear that while the LOSC and the IA provide the broad environmental mandate of the ISA, significant gaps remain. The agreements include few specific environmental measures and fail to provide guidance on how to implement them. For example, although emergency orders are required, the LOSC does not specify how these orders by the ISA could be financed and implemented in practice. ${ }^{66}$ Similarly, Article $165(2)(\mathrm{d})$ requires the Legal and Technical Commission to 'prepare assessments of the environmental implications of activities in the Area.' Yet, beyond this provision, the Convention does not specify the role and scope of such an environmental assessment in the decision-making process of the ISA. Such specific considerations were reserved for a later stage, partly because during the negotiations for the LOSC and the IA, understanding of the deep oceans was rudimentary and seabed mining remained a challenging future activity for which the required technology only existed in sketchbooks. Instead, the ISA's environmental obligations are developed further through the Mining Code, which sets out specific environmental standards and requirements. These complement the general obligations listed above and are best discussed in the context of the ISA's development of its environmental obligations mandate through the Mining Code, in Chapter 5.

\subsubsection{General Environmental Obligations of States}

While the ISA has a clear environmental protection mandate with respect to seabed mining activities in the Area, states have a corresponding obligation covering all human activities that impact the seas and oceans. This section

\footnotetext{
63 Armas-Pfirter (n. 6o), page 303.

64 UN Doc A/61/65 (n. 6o), paragraph 72; UN Doc A/67/95 (n. 59), paragraph 15.

65 Chapter 4.5 .

66 Chapters 5.4.4, 6.6.
} 
offers a brief discussion of several components of this obligation that in turn inform the ISA's environmental mandate.

As clearly and unambiguously stated in Article 192 of the LOSC, states have an unequivocal 'obligation to protect and preserve the marine environment.' This is complemented by the more specific obligation in Article 194(5) to 'protect and preserve rare or fragile ecosystems as well as the habitat of depleted, threatened or endangered species and other forms of marine life.' The latter, Warner notes, presents 'an early recognition of the need for ecosystem-based management of the Oceans. ${ }^{67}$ It can be seen as especially relevant for deep oceans with their exotic and fragile life forms, such as chemosynthetic ecosystems and cold-water corals. ${ }^{68}$

The significance of the prevalent obligation in Article 192 is further confirmed in Article 193, which reiterates the traditional sovereign right of states to exploit their natural resources yet expressly subjects it to the obligation to protect and preserve the marine environment.

What is noteworthy is that Article 192 refers generically to states rather than states parties, which allows for the interpretation that the obligation is a general principle of international law binding on all states. ${ }^{69}$ Since Part XII was developed following the adoption of numerous treaties on aspects of marine environmental protection, ${ }^{70}$ Article 192 'is the culmination of a process of adopting increasingly broad measures in different types of international instruments relating to marine environmental issues. ${ }^{71}$ It is this context that allows for the conclusion that the LOSC's provisions on marine environmental protection, including Article 192, form part of customary international law. ${ }^{72}$ In the ISA context, this means that non-member states are equally required to protect the marine environment from any potential seabed mining operations.

The concise formulation of Article 192 reflects the obligation to prevent marine pollution. In fact, Article 194 requires states to take 'all measures consistent with this Convention that are necessary to prevent, reduce and control

\footnotetext{
67 Warner (n. 58$)$, page 49 .

68 Scovazzi (n. 53), page 396.

69 See Nordquist et al. (n. 9), pages 39-40.

70 Chapter 4.3.

$71 \quad$ Nordquist et al. (n. 9), page 36 .

72 Philomène Verlaan, 'Marine Scientific Research: Its Potential Contribution to Achieving Responsible High Seas Governance' (2012) 27 The International Journal of Marine and Coastal Law 805-812, pages 810-811; Alan E. Boyle, 'Protecting the Marine Environment: Some Problems and Developments in the Law of the Sea' (1992) 16 Marine Policy, 79-85, 8o; Birnie, Boyle, and Redgwell (n. 6), pages 387-390.
} 
pollution of the marine environment from any source ${ }^{73}$ including from seabed mining operations ${ }^{74}$ but also from vessels, dumping, land-based activities, and atmospheric pollution. ${ }^{75}$ This obligation applies to all maritime areas, including the international seabed. ${ }^{76}$ Thus, one of the fundamental changes brought about by Part XII is that 'pollution can no longer be regarded as an implicit freedom of the seas. ${ }^{77}$ Importantly, however, this duty to prevent pollution is a due diligence obligation on states to take all necessary measures, yet 'using for this purpose the best practicable means at their disposal and in accordance with their capabilities. ${ }^{78}$ This addition reduces the force of the provision and implies a degree of flexibility, particularly for developing states. ${ }^{79}$ Interestingly, however, in the specific Articles dealing with pollution from seabed activities such discretion is absent. On the contrary, in controlling pollution from seabed activities, as well as pollution from vessels and dumping, ${ }^{80}$ states have to adopt measures that are no less effective than international rules and standards. ${ }^{81}$

As part of the duty to control pollution, states are required, under Articles 204 and 206 LOSC, to monitor the risks or effects of pollution and to assess potential environmental impacts of activities planned to be carried out within their jurisdiction or under their control. Pollution is defined broadly as:

the introduction by man, directly or indirectly, of substances or energy into the marine environment [...] which results or is likely to result in such deleterious effects as harm to living resources and marine life, hazards to human health, hindrance to marine activities, including fishing and other legitimate uses of the sea, impairment of quality for use of sea water and reduction of amenities. ${ }^{82}$

73 LOsC, article 194(1) (emphasis added).

74 LOSC, articles 194(3)(c), 196, 208, 209.

75 LOsC, articles 194(3), 207, 210-212.

76 Nandan, Lodge, and Rosenne (n. 11), page 197.

77 Birnie, Boyle, and Redgwell (n. 6), pages 383, 390.

78 LOsC, article 194(1).

79 See also LOsC, article 207(4); Jan Albers, Responsibility and Liability in the Context of Transboundary Movements of Hazardous Wastes by Sea: Existing Rules and the 1999 Liability Protocol to the Basel Convention (Springer, 2014), page 124-125.

80 LOSC, articles 210(6), 211(2).

81 LOSC, articles 208(3), 209(2).

82 LOsC, article $1(1)(4)$. 
This definition captures a wide range of interferences and could arguably allow noise, light, and heat pollution from exploration and exploitation activities to be included as forms of energy. ${ }^{83}$

In addition to outlawing marine pollution, Part XII also places the duty to control marine pollution into the wider context of the preservation of the marine environment. ${ }^{84}$ As such, the obligation goes beyond avoiding harm and includes the requirement to take active measures to enhance the state of the marine environment. ${ }^{85}$ As stated in the commentary to Part XII, this

goes much further than merely combating pollution after it has already taken place. It entails the active taking of legal and administrative measures, and the application of scientific methods and procedures which are all designed not simply to check or abate the deterioration of marine ecosystems, but also to provide the means for protecting and preserving the marine environment from the harmful effects of pollution and other hazards. ${ }^{86}$

Thus, Part XII introduces a proactive element requiring both states and international organisations to regulate and manage human activities before serious harm occurs. ${ }^{87}$

A further important point is that the obligation to protect and preserve the marine environment covers all marine spaces and affects the international community as a whole. Verlaan observes that it 'could even be argued that this obligation is on the verge of acquiring an erga omnes nature. 88 Indeed, the Seabed Disputes Chamber confirmed this assumption in relation to areas beyond national jurisdiction in its Advisory Opinion on the Responsibilities and

83 Harm M. Dotinga and Alex G. Oude Elferink, 'Acoustic Pollution in the Oceans: The Search for Legal Standards' (2000) 31(1-2) Ocean Development \& International Law 151-182, page 158; David Kenneth Leary, International Law and the Genetic Resources of the Deep Sea (Martinus Nijhoff Publishers, 2007), page 40-41.

84 Nordquist et al. (n. 9), pages 10-11; David Freestone, 'Problems of High Seas Governance' [2009] UNSW Faculty of Law Research Series 1-31, page 23.

85 Nordquist et al. (n. 9), pages 40-41.

86 Nordquist et al. (n. 9), page 11.

87 Birnie, Boyle, and Redgwell (n. 6), pages $383-384$.

88 Verlaan (n. 72), page 811; see also Albers (n. 79), pages 124-126. Erga omnes obligations are owed to the international community as a whole, enabling any state to invoke the responsibility of another state for a breach of this obligation, regardless of direct injury, see Barcelona Traction Case (Belgium v Spain) (Second Phase) [1970] ICJ Rep 3, paragraphs $33-34$. 
Obligations of States Sponsoring Persons and Entities with Respect to Activities in the Area (sDC Advisory Opinion). The Chamber was confronted with the question of who would be entitled to claim compensation from a state that sponsored activities in the Area following a breach of obligations and the occurrence of environmental harm. Referencing Article 48 of the International Law Commission's (ILC) Articles on State Responsibility, ${ }^{89}$ the Chamber concluded that 'each State Party may [...] be entitled to claim compensation in light of the erga omnes character of the obligations relating to preservation of the environment of the high seas and in the Area. ${ }^{90}$ The importance of this statement should not be lost. The Chamber offered 'the first indication of the existence of a right of actio popularis arising under an international environmental treaty outside the context of non-compliance procedures. ${ }^{\cdot 91}$ Nonetheless, it should be noted that much of the stringency of the $S D C$ Advisory Opinion was informed by the common heritage nature of the Area and its resources. ${ }^{92}$ Thus, the findings of the Seabed Disputes Chamber must be understood within the context of the ISA regime and might not be generalisable per se.

In summary, the LOSC imposes a far-reaching general obligation on states to protect and preserve the marine environment, including from pollution. This not only complements the ISA's environmental mandate but may also affect its enforceability in so far as the erga omnes nature of the obligation to protect the marine environment beyond national jurisdiction may allow any state to commence proceedings against a non-complying state.

\subsection{Gradual Integration of Precaution into the LOSC}

Despite the LOSC conferring a far-reaching environmental mandate onto the ISA and states parties, an important provision is missing in the Convention and

89 International Law Commission, Articles on Responsibility of States for Internationally Wrongful Acts, reprinted in 'Report of the International Law Commission on its Fifty-third session', Un Doc A/56/10 (2001).

90 Responsibilities and Obligations of States Sponsoring Persons and Entities with Respect to Activities in the Area (Advisory Opinion) (Seabed Disputes Chamber, Case No. 17, 1 February 2011), paragraph 180.

91 Philippe Sands and Jacqueline Peel, Principles of International Environmental Law (3rd edn, Cambridge University Press, 2012), page 732; see also Duncan French, 'From the Depths: Rich Pickings of Principles of Sustainable Development and General International Law on the Ocean Floor-the Seabed Disputes Chamber's 2011 Advisory Opinion' (2011) 26 The International Journal of Marine and Coastal Law 525-568, pages $545^{-546 .}$

$92 \quad$ French (n. 91), page 544 . 
the IA: the express obligation to apply precaution. It is submitted, however, that this obligation can be read as being implicit in the Losc.

The LOSC does not mention the precautionary principle per se. However, it does require both states parties and the ISA to take actions associated with precaution, such as conducting scientific research, environmental impact assessments, and declaring protected areas from seabed mining. ${ }^{93}$ Moreover, the LOSC allows for provisional measures 'to prevent serious harm to the marine environment. ${ }^{94}$ As Judge Treves stated in his separate opinion in the Southern Bluefin Tuna cases, 'a precautionary approach seems to me inherent in the very notion of provisional measures. ${ }^{95}$ Similarly, in his separate opinion, the late Judge Laing observed that given the numerous environmental protection provisions of the LOSC, 'it cannot be denied that [the Convention] adopts a precautionary approach. 96

The negotiations for the LOSC predate the rise of the precautionary approach in international law. However, with the mainstreaming of environmental awareness, the concept - even if not the precise language - of precaution has well and truly arrived in the law of the sea. ${ }^{97}$ As discussed in Chapter 2.2.3, there is mounting evidence of the precautionary principle having become binding as a rule of customary international law. ${ }^{98}$ As a living instrument, the LOsC must be interpreted in light of more recent developments in international law, ${ }^{99}$ including the widespread acceptance of the precautionary

93 LOSC, articles 143, 162(2)(x), 165(2)(d), (l), 256, 206.

94 LOsc, article 290(1).

95 Southern Bluefin Tuna Cases (New Zealand v Japan, Australia v Japan) (Provisional Measures) (Itlos Cases No. 3 \& 4, 27 August 1999) (Separate Opinion of Judge Treves), paragraph 9; see also $M / V$ 'Louisa' Case (Saint Vincent and the Grenadines $v$. Kingdom of Spain) (Provisional Measures) (ITLos Case No. 18, 23 December 2010) (Dissenting Opinion of Judge Wolfrum), paragraph 4.

96 Southern Bluefin Tuna Cases (n. 95), paragraph 17; see also the argument by Malaysia in Case concerning Land Reclamation by Singapore in and around the Straits of Johor (Malaysia v. Singapore) (Provisional Measures), verbatim record of 25 September 2003, ITLOS/PV.03/02/Corr.1, pages 17-20.

97 Rosemary Rayfuse, 'Precaution and the Protection of Marine Biodiversity in Areas beyond National Jurisdiction' (2012) 27 The International Journal of Marine and Coastal Law $773-781$.

98 SDC Advisory Opinion, paragraph 135; Arie Trouwborst, Evolution and Status of the Precautionary Principle in International Law (Kluwer Law International, 2002).

99 VCLT, article 31(3); see also Losc, article 138; Alan Boyle, 'Further Development of the Law of the Sea Convention: Mechanisms for Change' (2005) 54 International \& Comparative Law Quarterly 563-584; Birnie, Boyle, and Redgwell (n. 6), page 388. 
principle as evidenced by its incorporation in numerous treaties and other international instruments since the early $1990{ }^{100}$

Indeed, eminent support for this evolutionary approach has been provided by the International Court of Justice (ICJ) in the recent Whaling in the Antarctic case. In following the judgments in both the Gabčikovo-Nagymaros case ${ }^{101}$ and the Pulp Mills case, ${ }^{102}$ Judge Ad Hoc Charlesworth noted in her separate opinion that 'treaties dealing with the environment should be interpreted wherever possible in light of the precautionary approach, regardless of the date of their adoption.' ${ }^{103}$ Similarly, Judge Cançado Trindade in his separate opinion reiterated that international treaties and conventions are products of their time, and their interpretation and application in time, with a temporal dimension, bears witness that they are indeed living instruments. ${ }^{\prime 04}$ Highlighting the importance of interpreting the International Convention for the Regulation of Whaling (ICRW) in light of precaution, Judge Cançado Trindade observed:

It has been made clear, in recent decades, that the international community has adopted a conservation-oriented approach in treaty regimes, including treaties covering marine mammals. The ICRW Convention is to be properly interpreted in this context; it does not stand alone as a single international Convention aimed at conservation and management of marine mammals. The ICRW Convention is part of a plethora of international instruments adopted in recent years, aiming at conservation with a precautionary approach. ${ }^{105}$

This approach mirrors that articulated 15 years earlier in the Southern Bluefin Tuna cases by Judges Treves and Laing, who noted in their separate opinions

\footnotetext{
100 Chapter 2.2.2.

101 Gabčíkovo-Nagymaros Project (Hungary v Slovakia) (Judgment) [1997] ICJ Rep 78, paragraph 140.

102 Pulp Mills on the River Uruguay (Argentina v. Uruguay) (Judgment) [2010] ICJ Rep 71, paragraph 164 .

103 Whaling in the Antarctic (Australia v Japan: New Zealand intervening) (Judgment) (ICJ, 31 March 2014) (Separate Opinion of Judge Ad Hoc Charlesworth), paragraph 9; see also Legal Consequences for States of the Continued Presence of South Africa in Namibia (South West Africa) notwithstanding Security Council Resolution 276 (1970) (Advisory Opinion) [1971] ICJ Rep 31, paragraph 53.

104 Whaling in the Antarctic (n. 103) (Separate Opinion of Judge Cançado Trindade), paragraph 34 .

105 Ibid., paragraph 57.
} 
that the LOSC should be interpreted in accordance with the precautionary approach. ${ }^{106}$

Importantly, the clearest judicial endorsement to date of the precautionary principle by an international tribunal dealt specifically with the Part XI regime. In its 2011 SDC Advisory Opinion, the Seabed Disputes Chamber clearly demonstrated its willingness to take an evolutionary approach to interpreting the Part XI regime in light of current environmental concerns, particularly with regard to the applicability of the precautionary approach. ${ }^{107}$ The Chamber found an obligation on sponsoring states to apply precaution both as a direct obligation under the ISA Exploration Regulations ${ }^{108}$ and as an element of their general obligation of due diligence. ${ }^{109}$ While the former are discussed in detail in Chapter 5.3, the latter deserves close attention here.

Article 139(1), similar to Article 4(4) of Annex III to the LOsc, establishes a general responsibility of states to ensure that any entity they sponsor to carry out activities in the Area does so 'in conformity with this Part.'110 The Chamber linked this obligation of due diligence with the environmental obligations under the ISA regime, including the ISA Regulations. Thus, the Chamber noted that:

[I]t is appropriate to point out that the precautionary approach is also an integral part of the general obligation of due diligence of sponsoring States, which is applicable even outside the scope of the Regulations. The due diligence obligation of the sponsoring States requires them to take all appropriate measures to prevent damage that might result from the activities of contractors that they sponsor. ${ }^{111}$

In finding this connection, the Chamber relied on an 'implicit' link between an obligation of due diligence and the precautionary approach in the Southern Bluefin Tuna cases. ${ }^{112}$ Moreover, the Chamber noted that under the ISA standard clauses for exploration contracts 'the precautionary approach is a contractual

106 Southern Bluefin Tuna Cases (n. 95) Separate Opinion of Judge Treves, paragraph 9 and Separate Opinion of Judge Laing, paragraphs 12-21; see also Alan Boyle, 'The Environmental Jurisprudence of the International Tribunal for the Law of the Sea' (2007) 22(3) The International Journal of Marine and Coastal Law 369-381, pages 373-374. SDC Advisory Opinion, paragraph 135.

108 Ibid., paragraph 127.

109 Ibid., paragraphs 131-132.

110 Ibid., paragraphs 107-116; see also LOSC, article 153(4).

111 Ibid., paragraph 131.

112 Ibid., paragraph 132; Southern Bluefin Tuna Cases (n. 95), paragraphs 77, 79, 80. 
obligation of the sponsored contractors whose compliance the sponsoring State has the responsibility to ensure.'113 What is important to note for present purposes is that the Chamber demonstrated a willingness to interpret the responsibility of sponsoring states under the LOSC in line with the more recent obligation to apply a precautionary approach. What is more, by viewing the precautionary approach as part of the due diligence obligation, the Chamber extended its application even to activities outside the ISA mining regulations. ${ }^{114}$ As French notes, 'through this, the Chamber has refashioned States' general obligations to take into account more recent legal developments.'115 In line with the precautionary principle, the Chamber highlighted that the standard of due diligence may change with new scientific or technological knowledge and that 'the standard of due diligence has to be more severe for the riskier activities.'116

Such prominent support from international courts and tribunals for an evolutionary approach leaves no doubt that the LOSC must now be interpreted in light of the precautionary approach. This assertion is supported by Boyle's analysis of the environmental jurisprudence of the International Tribunal for the Law of the Sea in its first decade of existence, in which he found that the Tribunal had demonstrated a 'willingness to interpret and apply Part XII of the Convention consistently with the contemporary state of international environmental law.'117 Scholars have also argued that the LOsC must be applied in accordance with the precautionary approach. ${ }^{118}$ Moreover, adding political

\footnotetext{
113 SDC Advisory Opinion, paragraph 133.

114 Ibid., paragraph 131.

115 French (n. 91), page 547.

116 SDC Advisory Opinion, paragraph 117.

117 Boyle (n. 106), page 380.

118 Myron H. Nordquist et al. (eds), United Nations Convention on the Law of the Sea, 1982: A Commentary, Volume III (Martinus Nijhoff Publishers, 1995), page 288; Nico Schrijver, The Evolution of Sustainable Development in International Law: Inception, Meaning and Status (Martinus Nijhoff Publishers, 2008), page 185; Alex G. Oude Elferink, 'Governance Principles for Areas beyond National Jurisdiction' (2012) 27 The International Journal of Marine and Coastal Law 205-259, pages 225-227; Boyle (n. 99), pages 573-574; Bénédicte Sage-Fuller, The Precautionary Principle in Marine Environmental Law: With Special Reference to High Risk Vessels (Routledge, 2013), pages 68-70; Birnie, Boyle, and Redgwell (n. 6), pages 388-389;; David Freestone, 'International Fisheries Law Since Rio: The Continued Rise of the Precautionary Principle' in Alan Boyle and David Freestone (eds), International Law and Sustainable Development: Past Achievements and Future Challenges (Oxford University Press, 2001) 135-164, pages 135-164.
} 
support for a progressive interpretation of the LOSC, the UN General Assembly invited:

the relevant global and regional bodies, in accordance with their mandates, to investigate urgently how to better address, on a scientific basis, including the application of precaution, the threats and risks to vulnerable and threatened marine ecosystems and biodiversity in areas beyond national jurisdiction; how existing treaties and other relevant instruments can be used in this process consistent with international law, in particular with the Convention [on the Law of the Sea], and with the principles of an integrated ecosystem-based approach to management, including the identification of those marine ecosystem types that warrant priority attention; and to explore a range of potential approaches and tools for their protection and management. ${ }^{119}$

This call, together with the endorsement by judicial bodies and supportive arguments by numerous scholars, leaves no doubt that the law of the sea has moved on. The precautionary approach can be interpreted into the Losc. The next chapter examines the manner in which the IsA itself has confirmed the applicability of the precautionary approach in the seabed mining context. Before turning to that discussion, however, the next section offers a brief overview of the current limits of the ISA's mandate with particular reference to the issue of bioprospecting.

\subsection{The Debate about Bioprospecting and Marine Scientific Research in the Context of the ISA's Mandate}

A discussion about the ISA's environmental mandate would not be complete without a brief look at the current debate around bioprospecting, which also affects the ISA's mandate. As noted in Section 4.3.2 above, the economic potential of marine genetic resources has sparked a fierce debate over who should have access to these resources and how the benefits might be shared. Although a detailed analysis of the debate is beyond the scope of this study, this section outlines how bioprospecting is linked with the IsA's environmental obligations as well as its mandate to conduct marine scientific research. It should be noted

119 UNGA, UN Doc A/RES/58/240 (5 March 2004), paragraph 52 (emphasis added). 
that there is no agreed definition of bioprospecting but it broadly involves the search for and usage of genetic material for commercial purposes. ${ }^{120}$

The LOSC does not specifically regulate bioprospecting as it predates the discovery of the economic potential of marine genetic resources. ${ }^{121}$ Nonetheless, there is, as Scovazzi formulates it, 'an inextricable factual link between the protection of the deep sea-bed environment (including its biodiversity), marine scientific research and bioprospecting.'122 The ISA has established competencies with respect to the first two activities. Its environmental protection mandate is discussed in Section 4.3.2 above. Its competencies with respect to marine scientific research are summarised here.

Pursuant to Article 143(2) LOSC, the Authority is obliged to promote and encourage the conduct of marine scientific research in the Area, and coordinate and disseminate the results. As such, the ISA serves as a focal point for deep sea research. ${ }^{123}$ The IA classifies this obligation as a priority focus to be pursued before the start of the exploitation phase and highlights the need to place 'particular emphasis on research related to the environmental impact of activities in the Area.'124 A further priority task for the ISA is to acquire scientific knowledge and monitor the developments in marine technology 'in particular technology relating to the protection and preservation of the marine environment.' 125 Additionally, the ISA is mandated to carry out marine scientific research itself 'concerning the Area and its resources' and may enter into contracts for that purpose. ${ }^{126}$

In addition to the ISA's mandate, all states parties also have a right to conduct marine scientific research ${ }^{127}$ in areas beyond national jurisdiction, ${ }^{128}$ including the Area. ${ }^{129}$ States are to promote international cooperation in such

120 David Leary et al., 'Marine Genetic Resources: A Review of Scientific and Commercial Interest' (2009) 33 Marine Policy 183-194.

121 Armas-Pfirter (n. 6o), pages 303-304.

122 Scovazzi (n. 53), page 384 .

123 Satya Nandan, 'Administering the Mineral Resources of the Deep Seabed' in David Freestone, Richard Barnes, and David Ong (eds) The Law of the Sea: Progress and Prospects (Oxford University Press, 2006) 75-92, page 82.

124 IA, annex section $\mathrm{l}(5)(\mathrm{h})$.

125 IA, annex section $1(5)(\mathrm{i})$.

126 Losc, article 143(2).

127 For a discussion on the interplay between marine scientific research and the obligation to protect the marine environment see Verlaan (n. 72).

128 LOSC, articles $87(1)(\mathrm{f}), 238,257$.

129 LOSC, articles 143(3), 256. 
research, which may include participating in international programmes. ${ }^{130}$ In particular, they are required to cooperate in and promote research about pollution of the marine environment. ${ }^{131}$ In fact, the UN General Assembly has recently called upon

States, individually or in collaboration with each other or with competent international organizations and bodies, to continue to strive to improve understanding and knowledge of the oceans and the deep sea, including, in particular, the extent and vulnerability of deep sea biodiversity and ecosystems, by increasing their marine scientific research activities in accordance with the Convention. ${ }^{132}$

Against the background of the ISA's mandate over environmental protection and marine scientific research, the question is whether the ISA has any competencies with respect to bioprospecting? ${ }^{133}$

Here, the starting point must be whether bioprospecting might be regarded as marine scientific research in the Area. While research in the high seas can be carried out freely, research in the Area, pursuant to Article 143(1) must be 'carried out exclusively for peaceful purposes and for the benefit of mankind as a whole, in accordance with Part XIII.' ${ }^{134}$ The question then is whether bioprospecting, given that many marine genetic resources occur around the international seabed, that is the Area, falls under Article 143(1). This raises two questions. The first links back to the aforementioned debate in Section 4.3.2 around whether or not marine genetic resources are part of the Area or the water column. The reality likely lies somewhere in between, since several of these species, many of which remain unknown at present, will impudently ignore imaginary delineations drawn by lawyers and politicians.

Second, it would appear from the non-restrictive wording of Article 143(1) that research in the Area is not limited to mineral resources. Instead, as ArmasPfirter highlights, it refers to research in the entire geographical space of the Area $^{135}$ including its living resources. Thus, bioprospecting could in principle

\footnotetext{
130 LOSC, articles 143(3), 242.

131 LOSC, article 200.

132 UNGA, UN Doc A/RES/68/70 (9 December 2013), paragraph 222 (emphasis added).

133 See for example Lyle Glowka, 'Putting marine scientific research on a sustainable footing at hydrothermal vents' (2003) 27(4) Marine Policy 303-312; Armas-Pfirter (n. 6o); Scovazzi (n. 53).

134 LOSC, article 143(1) (emphasis added).

135 Armas-Pfirter (n. 6o), page 299.
} 
be subject to Article 143(1) provided that marine genetic resources are understood as forming part of the Area. However, the mandate of the ISA has been defined narrowly with a focus on mineral resources. ${ }^{136}$ Its current mandate extends to the protection of the entire marine environment, including marine genetic resources and their habitat, yet only from the harmful effect of seabed mineral mining activities. ${ }^{137}$

Nonetheless, the ISA's work is relevant for bioprospecting activities. Research carried out in the context of prospecting or exploration for minerals can also provide valuable scientific knowledge or result in the discovery of new genetic resources. Indeed, in order to establish environmental baselines to assess the impact of mining activities, the flora and fauna present at a potential mining site need to be catalogued and studied. The unresolved question is whether any conditions apply with respect to contractors commercialising any genetic information they discover during mineral exploration work. Thus, while the competencies of the ISA do not, at present, extend to all aspects of bioprospecting, in particular the questions of sharing economic benefits derived from bioprospecting, the ISA's work inevitably affects both research into marine genetic resources around mineral deposits and the conservation of these living organisms from seabed mining, for example around hydrothermal vents.

In theory, the ISA's mandate could be expanded in the future to specifically include bioprospecting. In this context, a number of states and nongovernmental organisations have been lobbying for a new international agreement, possibly an implementing agreement to the LOSC, to regulate the protection of marine biodiversity in areas beyond national jurisdiction, ${ }^{138}$ including marine genetic resources. ${ }^{139}$ Such an agreement could potentially

136 Chapter $3 \cdot 3$.

137 LOSC, article 145; Section 4.3.2.

138 ввNJ Working Group, Un Doc A/69/780* (13 February 2015); ввNJ Working Group, UN Doc A/66/119 (30 June 2011), paragraph 42.

139 For a discussion of the current framework for marine biodiversity in areas beyond national jurisdiction, see Robin M. Warner, 'Conserving Marine Biodiversity in Areas beyond National Jurisdiction: Co-Evolution and Interaction with the Law of the Sea' (2014) 1 Frontiers in Marine Science 1-11; Jeff Ardron et al., 'The Sustainable Use and Conservation of Biodiversity in ABNJ: What Can Be Achieved Using Existing International Agreements?' (2014) 49 Marine Policy 98-108; Kristina M. Gjerde, 'Challenges to Protecting the Marine Environment beyond National Jurisdiction' (2012) 27 The International Journal of Marine and Coastal Law 839-847. 
establish a system of access to and benefit sharing of marine genetic resources and define the role of the ISA in this system. ${ }^{140}$

However, opinions over the desirability of such an agreement diverge. ${ }^{141}$ Momentum was gained in 2011, when for the first time the EU and the $\mathrm{G}_{77}{ }^{142}$ plus China and Mexico agreed on a common position favouring a 'package deal' addressing issues concerning marine scientific research, marine protected areas, environmental impact assessments, capacity-building and the transfer of marine technology. ${ }^{143}$ The $u N$ Ad hoc Open-ended Informal Working Group to study issues relating to the conservation and sustainable use of marine biological diversity beyond areas under national jurisdiction recommended the initiation of a process to establish a legal framework for marine biodiversity. After lengthy negotiations, in January 2015, the Working Group adopted a formal recommendation to develop a legally binding agreement, ${ }^{144}$ which was adopted by the UN General Assembly in June $2015 .{ }^{145}$ A preparatory committee will work from 2016 to 2017 to 'make substantive recommendations to the General Assembly on the elements of a draft text of an international legally binding instrument under the [LOSC].'146 Subsequently, the UN General Assembly will 'decide on the convening and on the starting date of an intergovernmental conference, under the auspices of the United Nations, to consider the recommendations of the preparatory committee on the elements and to elaborate the text of an international legally-binding instrument under the Convention. ${ }^{147}$ A new agreement, if and when it will be adopted, could affect the ISA's mandate with respect to the protection of the marine environment but also bioprospecting. However, it will likely take several years until an agreement is reached..$^{148}$

140 For a detailed discussion on the various options, see Elisabeth Druel and Kristina M. Gjerde, 'Sustaining Marine Life beyond Boundaries' (2014) 49 Marine Policy 90-97, page 93; David Leary, 'Moving the Marine Genetic Resources Debate Forward: Some Reflections' (2012) 27 The International Journal of Marine and Coastal Law 435-448.

141 See for example un Doc A/67/95 (n. 59), paragraph 41-47; Elisabeth Druel et al., A Long and Winding Road - International Discussions on the Governance of Marine Biodiversity in Areas beyond National Jurisdiction (Studies No. 07/13, IDDRI, 2013), page 23-33.

142 The Group of 77 is a group of states that cooperate at UN level $<w w w . g 77 . o r g\rangle$.

143 UN Doc A/66/119 (n. 138), paragraphs 17, 42; Druel et al. (n. 141), page 23.

144 UN Doc A $/ 69 / 780^{*}$ (n. 138).

145 UNGA, UN Doc A/REs/69/292 (19 June 2015).

146 UN Doc A $/ 69 / 780^{*}$ (n. 138), paragraph $1(e)$.

147 Ibid.

148 For a discussion of the recent developments, see Julien Rochette et al., 'A New Chapter for the High Seas?' [2015] IDDRI Issue Brief No. 02/15. 
Importantly, the current environmental mandate of the ISA exists independently of these ongoing discussions for a potential new implementing agreement. Regardless of any future developments, the ISA is already under an obligation to ensure that seabed mining, as a new human activity with the potential to have serious impacts on marine biodiversity, does not become another item on the list of perils to the marine environment.

\subsection{Conclusion}

During early discussions for a potential international regime for seabed mining, it was already recognised that environmental damage from seabed mining will have to be regulated and minimised. Throughout the negotiations for the LOSC and the IA widespread awareness of the urgent need to address environmental concerns increased. To address this concern, the LOsC incorporated a broad obligation on states to protect and preserve the marine environment. In order to integrate Part XI with the Convention's environmental conservation objective, the LOSC confers upon the ISA a far-reaching environmental mandate to take such measures as the ISA considers 'necessary' to protect the marine environment, as a broad ecological space, from harm caused by seabed mining. The IA further strengthens this mandate by identifying environmental protection as a priority issue. Although the LOSC does not explicitly require the ISA to apply the precautionary approach, it is clear that such obligation can now be interpreted into the Convention.

Consequently, the ISA is equipped with both a mandate to organise, carry out, and control seabed activities in the Area on behalf of humankind as a whole and to protect the marine environment, through a precautionary approach. It is the ISA's responsibility to balance both interests and to fill the legal gaps left by the LOSC and the IA with respect to specific environmental measures and ways to implement these. The mandate to take 'necessary measures' enables the ISA to think outside the box and proactively develop environmental management standards for seabed mining to fulfil the broad objectives of the LOSC and the IA. As the next chapter discusses, the first step in implementing its broad environmental mandate is for the ISA to adopt specific rules, regulations, and procedures forming part of the Mining Code. 